\title{
The Great War and the Middle East
}

\section{Dr Rob Johnson}

This year, 2017, is the centenary of the publication of the Dardanelles Commission, the 'Chilcott Report' of its day, which examined the causes of the setback at Gallipoli in 1915. The naval operations and the subsequent amphibious landings have been remembered as a costly failure, even a hopeless folly with no chance of success and the images of that campaign are powerful. Yet, few ever mention the final vignette of 1918, when Allied soldiers once again landed on the scrubby peninsula of Gallipoli, and captured its airstrips, while the Royal Navy steamed through the Dardanelles to level their guns on the Ottoman capital, Constantinople. The flotilla was led by HMS Agamemnon, the vessel which had taken part in the attack of 1915, and which was used as the ship that led the delegation to Mudros where the Ottomans were forced to sign an armistice at the end of the war. Of course, it was a symbolic conclusion in another sense: in Classical times, King Agamemnon had humbled Troy at the gateway to the Dardanelles.

The campaigns of the Middle East, including the Dardanelles, were regarded as secondary theatres in this war, and it is fascinating to observe the continuing imbalance of publications towards events on the Western Front in what was, after all, a global conflict. The British Prime Minister, David Lloyd George had supported the Dardanelles offensive against the Ottomans as the strategic solution to the impasse in France and Flanders. He had argued that defeating the weaker Ottomans and then the Austro-Hungarians would 'knock away the props' of Germany. He rejected the accusation this was a waste of resources on side-shows. In the House of Commons, he maintained:

The British Empire owes a great deal to 'side-shows'. During the Seven Years' War, which was also a great European War ... the events which are best remembered by every Englishman are not the great battles on the Continent of Europe, but Plassey and the Heights of Abraham; and I have no doubt that, when the history of 1917 comes to be written, and comes to be read ages hence, these events in Mesopotamia and Palestine will hold a much more conspicuous place in the minds and memories of the people than many an event which looms much larger for the moment in our sight. ${ }^{1}$

Lloyd George was perhaps mistaken about posterity, but there was much to this idea that the war had required a strategic approach which, too often today, is overlooked as scholars and the public dwell on the micro-histories of people's war experiences in the trenches. The making of strategy is a subject of considerable importance in the history of the First World War. The calculations of the decision-makers are significant. If we are to avoid condemning our ancestors and forebears for merely engaging in a meaningless and futile war, (which can be the only judgement if one pursues micro-historical experiences alone) then we must surely seek to understand what directions they made, and why, and how they reached their decisions.

What emerges from this examination of higher level decision-making is that the Middle East was not a sideshow but the imperial meridian. The Suez Canal, for example, was the axis of the British Empire's war effort. Moreover, rather than a series of separate and unconnected campaigns, which we get from individual campaign histories of Gallipoli or Palestine, the strategies of the Middle East indicate that they were interconnected and interdependent. Actions and reactions were reciprocal and dynamic.

Any assessment of the decision-making cannot, of course, be limited solely to the British, and the strategic interaction of decisions includes the Ottoman Empire, France, Russia, and Germany. It must also include the other polities of Persia and Afghanistan, and the Arab leaders, the minorities like the Kurds and Armenians, as well as the Egyptians, Sudanese and Libyans. All had a part to play in this significant drama. That is important because of the myths that perpetuate the condemnation of 'the West' for carving up and subjugating the Arab peoples, when, in fact, the 'agency' of all the actors in this conflict shaped the history of the region. There was no conspiracy to divide the Arabs, since they were

\footnotetext{
${ }^{1}$ Hansard, $5^{\text {th }}$ series, vol C., col. 2211.[1917]
} 
already bitterly divided, and indeed remained so. Advocates of Arab unification, like T. E. Lawrence were romantics sadly disillusioned by their experiences.

The paradox of the First World War from the British perspective is that they were eager to preserve the status quo in the region and yet did more than any other country to change and reorder it. The Middle East, under the Ottomans, gave Great Britain a security zone between the ambitious expansionist powers of Europe, and the vulnerable sea lanes and trade routes of the British Empire. At the outbreak of war, it was eager to maintain Ottoman neutrality or perhaps bring the Sublime Porte in on the side of the Entente. Germany was just as keen to draw the Ottomans into the conflict on their side, although some of the Kaiser's officers had personal reservations and concurred with the view, prevalent in Berlin, that the Ottoman domain was ripe for German colonisation. ${ }^{2}$ Contrary to popular belief, the real aggressors in the region were the Ottomans themselves, or rather, their relatively new and militaristic leadership. Although associated with defence against the grasping Western imperialists, it was the Ottoman triumvirate that initiated the war. Having suffered two humiliating defeats at the hands of the Balkan powers between 1912 and 1914, there was a strong desire for a war of revenge to recover lost territory. Moreover, Russia was regarded as the primary threat, not least because it occupied the former Ottoman territories in the Caucasus. Yet, above all, the Russians were regarded as a power covetous of Constantinople and the Bosporus Straits. It was no accident that the Ottomans started their war with an attack on the Russians.

The orthodox approach to the study of the Middle East in this period is to focus on the 'contradictory' assurances made by Britain towards the Arabs and minorities of the region or the apparently blatant imperialist schemes to divide lands between the British and French authorities. The infamous Sykes-Picot Agreement is the most cited in this regard. Yet the speculative arrangement between diplomats Sir Mark Sykes and Georges-Francois Picot was never binding, was never implemented, and was disowned by their governments before the war had even ended. The Balfour Declaration, drawn up this anniversary year in 1917, is similarly held aloft as an example of Allied perfidy towards the Arabs. But this too is a false charge. The declaration was very clear that while the British government 'viewed with favour' the foundation of a Jewish national homeland, it would not permit any polity to infringe the existing rights of the Arab peoples. It did not envisage a separate state of Israel, but a federation, not unlike the successful entities Britain had created with the formation of Canada or the Union of South Africa.

The focus on Sykes-Picot and Balfour's Declaration overshadows the far more important contemporary government enquiry of 1915, known as the de Bunsen Committee. ${ }^{3}$ Established by the then Prime Minister, Herbert Asquith, the committee was set up to make recommendations on Britain's desiridata (war aims) in the Middle East as a response to the Ottoman Empire's declaration of war the previous October. The strategic imperative was threefold: to curb German influence in the region; to block Russian expansion south of the Caucasus and the check French interference in the Middle East. It considered four options. One option was to partition a defeated Ottoman Empire, leaving the Turks with Anatolia. The second option was to preserve the Ottoman Empire, but to allocate spheres of influence and control, as had been done with Persia in 1907. A third option was to preserve the Ottoman Empire as it was, but without its Balkans possessions. The final option was to create a federated state with autonomous regions for the Arabs, Kurds and other groups. The British government chose the fourth option, for they envisaged the survival of the Ottoman apparatus, but with far greater freedom for its territories. Moreover, Britain was very eager to protect its existing allies and partners, including the

\footnotetext{
${ }^{2}$ Max von Oppenheim would later author Denkschrift betreffend die Revolutionierung der islamischen Gebiete unserer Feinde (Memorandum on Revolutionizing the Islamic Territories of Our Enemies). See The War: German attempts to fan Islamic feeling, L/PS/11/99 P 4180/1915 India Office Records, British Library, and V.R. Berghahn, Germany and the Approach of War in 1914 (London: Macmillan, 1973), p. 143.

${ }^{3}$ Committee of Imperial Defence: Asiatic Turkey, Report of a Committee, 30 June 1915, CAB 42/3/12. The National Archives, Kew.
} 
Sultanate of Muscat (Oman), the Trucial States (later UAE, of course), Kuweit, the Idrisis, the Sheikhs of southern Arabia (today's Yemen) and its colony at Aden.

What deflected these benign intentions? First, the war itself and the strategic interaction of the various belligerents. Second, the French colonial lobby, which wanted control of the eastern Mediterranean by the establishment of a colony in 'Greater Syria, including the holy sites of Palestine. French colonial politicians had not forgotten the loss of Egypt and Sudan to the British in the 1880s and 1890s and they were eager to extend their influence from their North African possessions. ${ }^{4}$

The British were less concerned about French aspirations than the more important threats to their interests. The first was the security of the Suez Canal. The second was the potential for internal unrest posed by their Muslim subjects. Suez was the strategic fulcrum of Britain's Empire in the east, and while there was no maritime threat of any magnitude in the region, the ominous remarks made by the Kaiser about building a fleet to rival the Royal Navy and the German objective to build an arterial railway from Berlin to Baghdad, which could draw commerce away from the coasts, had to be taken seriously. The internal security threat was perhaps even more serious. ${ }^{5}$ In November 1914, the Ottoman Caliph had issued a Fatwah against Britain and France, arguing that any Muslim subject of these empires must resist and join a global Jihad.

Ironically, it was the Ottoman Empire which faced the greater level of internal dissent to its rule. The political turmoil of the 1909 revolution and the ruthless Turkification threatened by the Committee of Union and Progress (CUP), better known as the Young Turks, caused considerable anxiety amongst the minorities of the Ottoman Empire. A series of authoritarian decrees, arbitrary punishment and a more assertive 'Turkish' policy was stirring resistance. ${ }^{6}$ Decades of Ottoman repression had already produced a nascent nationalism amongst more educated Syrians and Arabs. The defeats of the Balkan Wars had created a chaotic flight of Muslim refugees, an anguished desire for retaliation and economic recession. As the political factions in Constantinople vied for power, the militarist elements of the CUP, allied to the Third Army, advocated a desperate policy of war. Their German advisors pointed out that the Ottoman armed forces were not yet ready for a major conflict, but the fear of a lost opportunity, that is, to benefit from an eventual peace settlement, drove the CUP into the war.

The first difficulty was how the Ottomans should deploy their armed strength. Was the best strategy defensive, or should they strike while the Entente powers were occupied with the fighting in Europe? Djemal, the one member of the Triumvirate with strongly Islamist sentiments, advocated a triumphant advance on Suez, mobilising popular Muslim sentiment along the way. ${ }^{7} \mathrm{He}$ envisaged millions being inspired by the offensive, and he believed the Egyptians would surely rise up in favour of the Ottomans. He pleaded with the Senussi of Libya to attack the western border, while the Ottoman army crossed the Sinai to enter Egypt from the east.

Yet Enver, a second member of the triumvirate argued for an offensive against their primary adversary, the Russians, in the Caucasus. ${ }^{8}$ Enver's audacious plan was to advance in the depths of winter across the mountains to seize the nodal depot at Sarıkamıs. When his advisors pointed out that the army lacked the logistics or winter supplies for such a manoeuvre, Enver dismissed their complaints, arguing that all the supplies they needed lay before them, in Russian warehouses. The result of these two bifurcated offensives was total failure. Djemal's army was halted on the Suez Canal, thanks to British Yeomanry and Territorials, while the Senussi raiders were driven off by a scratch force hastily assembled from the garrison in Egypt. Enver's offensive was an even greater disaster. The freezing temperatures and blizzard

\footnotetext{
${ }^{4}$ David Fieldhouse, Western Imperialism in the Middle East 1914-1958 (Oxford: Oxford University Press, 2006), p. 49.

${ }^{5}$ For a contemporary view see: James Campbell Ker, Political Trouble in India, 1907-1917 (1917, reprintd., Calcutta, 1973).

${ }^{6}$ Ziya Golkap, The Principles of Turkism (Ankara, 1920; transld. Robert Devereux, Leiden, 1968), pp. 12-15.

${ }^{7}$ Djemal Pasha, Memories of a Turkish Statesman, 1913-1919 (London: Hutchinson \& Co., 1922), p. 154.

${ }^{8}$ Still the best account by far is William Edward David Allen and Paul Muratoff, Caucasian Battlefields: A History of the Wars of the Turko-Caucasian Border, 1828-1921 (Cambridge: Cambridge University Press, 1953; 2010 edn.)
} 
conditions killed hundreds, and the Russians regrouped to hold Sarkkamış, devastating three Ottoman divisions in the process. Enver's frostbitten survivor's staggered back into Erzurum, but the medical staffs were so overwhelmed that thousands more died of infectious diseases.

By contrast, the British assessment of the strategic situation in the winter of 1914 was more positive. The German army had been checked on the Marne and at Ypres, but the Western Front was now in stalemate. The Royal Navy, which had not yet had a chance to demonstrate its contribution to the war effort, despite a victory in the Falkland Islands, had shelled the Gallipoli peninsula with spectacular results. The magazine at the fortress at Sedd-ul Bair had exploded, destroying it entirely. A Royal Navy party had also gone ashore at Alexandretta and found the Ottoman local authorities co-operative. ${ }^{9}$ At Basra, the navy had landed a small Indian Army brigade, which had swept aside the Ottoman defenders and captured Basra. With the Ottoman defeats at Suez and the Caucasus, Winston Churchill, then First Lord of the Admiralty, was prompted to conclude: 'we were not dealing with a thoroughly efficient military power.' ${ }^{10}$

The Russians too were guilty of the charge of inefficiency. Their campaign in the winter of 1914 against East Prussia was a disaster and while they remained on the defensive in the Caucasus, Enver's offensive had come as a profound shock. The steep rise in prices and supply problems on the home front were exacerbated by the Ottoman severing of the Straits to shipping. Russia needed support, and the Western Entente powers needed to keep the Russians fighting to absorb as many divisions of the German and Austrian forces as possible.

There was, at this critical moment, little agreement on how to conduct the war in 1915. There were some advocating that the weakest element of the Central Powers, the Ottomans, should be knocked out of the war to persuade the Germans to sue for peace. There was a general consensus in the Asquith Cabinet that closer co-operation with France and Russia was desirable, although it was not until July 1915 that the principle of co-ordinated action was agreed upon. The strategic imperative was to get more neutral countries into the war, in order to generate a larger coalition against Berlin, Vienna and Constantinople. One way to do this was to focus on the Balkans, to get Italy, Greece, Bulgaria and Romania in on the Allied side.

The Government of India had its own agenda, namely the security of the Gulf, Persia and Afghanistan against the Ottomans and the Germans. A subversive group of German agents, replete with gold, set off in 1915 to persuade the Afghans and the Persians to join the pan-Islamic Jihad against the British, thence to set off a revolution in India. ${ }^{11}$

The British Army had a very different view. For them, the absolute priority was men and munitions for the fighting in France. They argued that only by defeating the German army in the field could this war be brought to a conclusion, and frittering away resources to peripheries was irresponsible. Churchill, like many others, knew Britain must achieve a decisive result - but where?

The Dardanelles plan received surprisingly little time or consideration. It was decided that a naval operation would open up the Straits for Russia and, at the same time, threaten Constantinople with bombardment. ${ }^{12}$ An inexperienced imperial force, stiffened by the last remaining regular army division, would act as an army of occupation, landing unopposed after the naval mission. The Ottoman view was that the Royal Navy was the most powerful of the world, and after the shelling of Sedd ul Bair in 1914, the Straits were mined extensively and the minefields protected by fixed and mobile artillery. The assumption was that the British would probably make landings, but these would come, it was thought, at Bulair, the narrow neck of the Gallipoli peninsula. Rehearsals for the invasion were conducted ceaselessly, and had their origins in the need to anticipate a Greek amphibious operation in the Balkan Wars. In that

\footnotetext{
${ }^{9}$ The party was led by Sir Richard Pierse.

${ }^{10}$ Martin Gilbert, Winston S. Churchill, vol. III, 1914-1916 (London: Heinemann, 1971), p. 222.

11 Robert Johnson, Spying for Empire (London: Greenhill, 2006).

${ }^{12}$ C.F. Aspinall-Oglander, Military Operations: Gallipoli (London: William Heinemann, 1929), I, pp. 51-3; Lord M.

Hankey, The Supreme Command, 1914-1918, I, (London: George Allen and Unwin, 1961), pp. $260-2$.
} 
conflict, the Greeks had estimated that a minimum of 150,000 men would be needed to capture Gallipoli. ${ }^{13}$ The British had only 73,000 for their subsequent landings.

The Royal Navy tried in vain to clear the minefields and force a passage through the Dardanelles for four weeks, but in one final effort in March 1915, they and their French allies lost several vessels. The landings that followed in April were contested just as strongly. In May and June, the fighting was reduced to stalemate. A vast Ottoman counter-offensive in August 1915 fared no better, with thousands of casualties. By the winter, it was clear that no further progress could be made by either side. The British withdrew. ${ }^{14}$

Too often, this campaign is viewed in isolation, but it was intimately connected with other events. The Caucasus front was denuded of Ottoman reinforcements because of the prioritisation of Gallipoli, where some 90 divisions eventually served, and that contributed to the fall of Erzurum to Russian forces in early 1916. For the British government, the Gallipoli campaign was supposed to persuade neutrals to come in, but while Italy joined the allies, Greece was divided and the Bulgarians sided with the Central Powers. ${ }^{15}$ The Italians pressed their own demands for territorial compensation, which complicated the Allied war objectives. To make matters worse, Britain felt compelled to acquiesce to a Russian demand to hand Constantinople over to the Tsar after the war when the Russians ratified their agreement to the SykesPicot agreement in 1916.

Within the Ottoman Empire, the failure of the Sarıamıs offensive, the fall of Erzurum and the proximity of the Allies to the capital in 1915 deepened anxiety about the future. There was already considerable suspicion about the loyalties of various minorities, and Christians especially. Armenians within the ranks of the Ottoman army were subject to degrees of ostracism, and actions by the police and security forces against concentrations of Armenians in northern Syria and eastern Anatolia, increased pressure and resistance. When Armenians protested and then fought back, it only magnified the anxieties of the Ottoman authorities. The reaction was severe and comprehensive, with murders, village burnings, and mass deportations into the deserts. Assyrian Christians were subjected to the same abuse, and the systematic, sustained nature of the killings were catastrophic. From a strategic point of view, the opportunity for many Muslim civilians to feel a sense of connection with or to participate in a war that had hitherto been remote, was welcomed. It helped mobilise the empire. Yet it also alienated many minorities, well beyond those in Christian regions. The Hashemite Arabs, for example, long under the threat of a purge by the Ottoman regime, observed the repression of Syrian nationalists and believed that it was only a matter of time before they too were attacked.

The British, especially the authorities in India, nevertheless had their own pressing strategic concerns. There had been an attempt to seize the opportunity to advance on Baghdad, in part to secure a prestige victory against the Ottomans that would reassure Muslim opinion within the British Empire that they were on the winning side. ${ }^{16}$ A mutiny of Indian Light Infantry at Singapore in 1915, men who believed they were being sent to fight their co-religionists in Mesopotamia, brought back chilling memories of the Indian Mutiny of 1857 and proved that the subversive threat had to be taken seriously. Taking Baghdad would, it was thought, demonstrate that Britain was the paramount power. But General Townshend's dash up the Tigris was checked at Ctesiphon and his force was besieged at Kut. The relief attempts cost the lives of 23,000 British and Indian troops and was fought in appalling conditions. The fall of Kut in April 1916 now added to British anxiety about Muslim opinion.

\footnotetext{
${ }^{13}$ Aspinall-Oglander, Military Operations: Gallipoli, I, (1929), pp. 101-110.

${ }^{14}$ The Final report of the Dardanelles Commission, Part II: Conduct of Operations, Cmd 371 (1919).

${ }^{15}$ See Paul Guinn, British Strategy and Politics, 1914 to 1918, (Oxford: Clarendon Press, 1965).

${ }^{16}$ Mesopotamia Commission Report, cd 8610 (1917), pp. 12-15; Brigadier General F.J. Moberly, The Campaign in

Mesopotamia, I, (London: Historical Section of the Committee of Imperial Defence, 1923). See also Charles

Townshend, When God Made Hell: The British Invasion of Mesopotamia and the Creation of Iraq, 1914-1921 (London: Faber and Faber, 2010).
} 
Pre-war conversations between Sir Henry MacMahon and Abdullah, the son and emissary of the Emir Hussein of the Hashemites, had been inconclusive, but the imperatives of the war made the British more favourably disposed to an arrangement. Hussein agreed to launch a revolt against the Ottomans in return for British approval, arms and perhaps even recognition of his claim to all Arabia. While Hussein aspired to lead all the Arab world, the British would only refer to him as the King of the Hejaz, as they did not wish to offend or abandon their existing partners, including Ibn Saud of Riyadh. Hussein regarded Ibn Saud as his bitterest enemy, as post-war events were to demonstrate.

The 'Arab' Revolt, launched in June 1916, was almost a disaster from the start. Fortunately, assistance appeared in the form of the Royal Navy and Royal Flying Corps, which defeated and deterred Ottoman operations against the Red Sea coast. North African, Egyptian and Indian troops joined some of the Arab contingents. British and French officers then acted as advisors and mentors, some engaging in the destruction of Ottoman railway lines that connected their garrison at Medina with Syria. Colonel Newcome, Major Garland and Captain (later Colonel) Lawrence were successful in this regard although the strategic impact of sabotage can often be exaggerated. Frustratingly for the British, the Hashemite revolt failed to do much more than pin down some Ottoman units. It did not release much pressure on Aden nor did it ignite widespread support. Arabs in Mesopotamia, for example, did not adhere to the Hashemite cause. Indeed, some Shia were inspired by the Ottoman 'discovery' of the Banner of Ali and their promises of unbroken victories against the Allies.

It certainly looked bleak for the Allies in 1917. Despite the arrival of new administrations in Britain and France, under the dynamic David Lloyd George and Georges Clemenceau respectively, and the entry of the United States into the war, the fortunes of the Allies deteriorated. Atlantic supplies were attacked by U-boats and German air forces gained the upper hand over the skies of France in the spring. Russia, which had ousted the Tsar in February and which had seemed poised to regenerate under democratic leadership now appeared to atrophy. When the Bolsheviks seized power in the autumn, Russia's war effort had dwindled to the point of collapse. Crowds demanded an end to the war, and condemned the Tsarist war aims. Russian units insisted on electing their own officers and in the Caucasus, as in other parts of the Russian Empire, the soldiers abandoned their regiments. To compensate for the collapsing eastern front, the Allies made renewed efforts in the west. The French Champagne offensive proved to be a disaster, and, after initial spring and summer successes at Arras, Vimy and Messines, the British offensive of Third Ypres bogged down. In Italy, there was a catastrophic defeat at Caporetto, which necessitated the transfer of British and French divisions to stabilise the line.

In the Middle East, it was a mixed picture in 1917. General Sir Archibald Murray, who commanded the Egyptian Expeditionary Force (EEF), had managed to take the whole Sinai and was poised to secure Palestine, but two determined offensives at Gaza met with failure. Yet in late 1916, when there was a prospect that a Russian Cossack formation might cross the Persian border and take Baghdad, General Sir Stanley Maude had been authorised to renew the offensive on the Tigris. ${ }^{17}$ It began in a style reminiscent of the film Desert Victory, with a gigantic artillery barrage. Unlike the film portrayal of the Second World War battle at El Alamein, the Second Battle of Kut was fought in the midst of a torrential downpour and the reverberating thunder of a storm. Ottoman soldiers clung to the melting mud walls of their trenches as salvoes of high explosive detonated around them. But the action was not over in a single night. The fighting went on for days, with small bites taken from the Ottoman defences by British and Indian troops. With overwhelming firepower and adroit manoeuvre, Maude then unhinged the defences around Kut and advanced on Baghdad. The city fell to the Allies in March 1917, and the British government, which was eager to ensure the government of India did not try to take control of the region for itself, asserted firm War Office control of this region of 'occupied enemy territory'.

The success of the Tigris operations was followed by the seizure of Aqaba in July 1917 by the embryo of the 'Arab Northern Army', namely Feisal, son of Hussein, and his military advisor T. E. Lawrence. The taking of Aqaba opened up the possibility of a new flanking action against the Ottomans and Lawrence

17 Moberly, Campaign in Mesopotamia, III, pp. 79, 86-90. 
reported the fact in person to General Allenby, who had succeeded Murray in Egypt. Allenby had been planning his own operations in Palestine and used the secured flank to make an enveloping manoeuvre at Beersheba with three infantry divisions and a fast-moving mounted corps. The twilight charges by the New Zealand Mounted Rifles and Australian Light Horse has become legend but their success drew Ottoman reserves eastwards, while feints pulled in more towards Gaza. Allenby then struck at the centre of the Ottoman defences at Hureira and Tell es Sheria, breaking through on a wide front. The Ottomans were driven back into the Judean Hills.

The Third Battle of Gaza, as it was known, opened up a renewed debate on strategy for the British, but also for the Central Powers. The British government, now a small War Cabinet led by Lloyd George, wanted to deliver a morale-boosting victory to sustain public resolve in the fourth winter of the conflict. He envisaged Allenby taking Jerusalem as a 'Christmas present for the British nation'. ${ }^{18}$ The Chief of the Imperial General Staff, General Sir William 'Wully' Robertson, supported by the General Headquarters of the army in France, vehemently disagreed. Robertson, facing genuine difficulties in allocating manpower and munitions, was keen to try to limit the grandiose ambitions of his Prime Minister. The government, now eager to exploit the success offered by the Middle East theatre, had raised the possibility of an amphibious attack on Alexandretta, despite the paucity of manpower and shipping then available. ${ }^{19} \mathrm{He}$ wrote to Allenby that: 'it will be a good thing to give the Turk in front of you a sound beating, but that the extent to which we shall be justified in following him by an advance into Northern and Central Palestine is a matter which for the moment must be left open. ${ }^{20}$ Referring to the Clausewitzian problem of a culminating point, where an advancing army exhausts its supplies and manpower, he added: 'The further we go north the more Turks we shall meet; and the greater will be the strain upon our resources.' He added a 'PS', in which he pointed out it was not so much going forward that he opposed, but how to 'maintain ourselves after going forward and to a useful purpose.'

Lloyd George was so exasperated by Robertson that he tried to have Sir Henry Wilson replace him as Chief of the Imperial General Staff, but when that looked unlikely to succeed, he tried to give command of British forces in France to the French. He even tried to take control of a large-scale strategic reserve, which the army desperately needed to stave off an imminent German offensive involving many divisions. This looming attack was regarded as a very serious threat by British military leaders. Lloyd George was more concerned that the army was not profligate with the lives of soldiers so critical, not only to the defence of France, but to the future of the country and the empire.

Released from the Eastern Front, where Russian resistance had collapsed, in early 1918 the German army was confident that it could defeat the British and French before the Americans entered the war in large numbers. Indeed, they were so confident that Germany produced its own version of a peace plan to reorder Europe. Russia had signed the Treaty of Brest-Litovsk and the Romanians were forced to capitulate, so the possibility of a separate peace by any of the Allied nations, which the British had feared would undermine their war efforts, now seemed a distinct possibility for other powers. The Ottomans too could foresee a post war world where they recovered the Caucasus and created a new Turkic empire, jettisoning the troublesome and economically burdensome Arab territories in the process.

The Hashemites were in an awkward situation. They were dependent on British and French support, especially for money, arms and munitions, to sustain the revolt. By late 1917, the Arab revolutionaries enjoyed air support, the provision of armoured cars, heavy machine gun teams and light artillery. Yet the publication of the 'secret treaties' by the Bolsheviks that year revealed that there had been, at least until May 1916, a Sykes-Picot agreement. The Hashemite reaction was restrained as they already knew of the contents, but it came soon after Ottoman attempts to reconcile with Arab factions of all hues. Djemal

\footnotetext{
18 Archibald Wavell, Allenby: A Study in Greatness (London: 1940), p. 186; John Grigg, Lloyd George: War Leader (London: Allen Lane, 2002), p. 150.

${ }^{19}$ Cyril Falls and A.F. Becke, Military Operations, Egypt and Palestine, II, (London: HMSO, 1930), p. 27.

${ }^{20}$ Robertson to Allenby, 1 August 1917, 8/1/67, Robertson Papers, Liddell Hart Centre for Military Archives, London.
} 
had written to Hussein and Feisal offering for them to come back to the Ottoman cause after the fall of Aqaba, but the correspondence was passed on to the British without comment. The Hashemites knew what would lie in store for them under a victorious Ottoman regime. Djemal had rather more success in dividing the Arabs. When General Allenby made an attempt to capture Amman, some of his Arab 'allies' were clearly in league with the Ottomans and disclosed the operational plans, with inevitable results.

Yet there was discord on the Central Powers' side too. Tensions had existed between the Ottomans and their German partners since the start of the war. There was growing distrust between some Ottoman commanders and the senior German officers, especially as the armies were driven back in Sinai, Palestine and Mesopotamia. One issue brought matters to a head, and that was the decision about where to deploy the final strategic reserve known as Yildırım (Lightning). Augmenting this force was supposed to be the German Pasha II formation, a reinforced brigade bristling with a higher than normal proportion of light artillery, machine guns and highly-experienced troops. There were heated discussions about where these forces should concentrate: against the British in Palestine to bolster the approaches to Syria and southern Anatolia; against Baghdad so as to recover an important prestige symbol; against Persia to force the British to divert resources there and so relieve pressure on Palestine; in the Balkans, to support the Bulgarian and German units there; or against the Caucasus in order to acquire oil resources at Baku and Mosul, or to create territories that could be relinquished in the bargaining of the post war peace. The debate raged, and personal animosities surfaced. General Falkenhayn was blamed for the failure to hold southern Palestine and Mustaphal Kemal refused to serve under any German officers. He argued that the Arab territories should be abandoned and a new defensive line established in the Anatolian hills.

Enver had not given up hope of redeeming himself in the Caucasus and his force moved against the pusillanimous remnants of the Russian army, and the more determined Armenian corps, which believed the existence of its people now hung in the balance. The Ottoman units then collided with the German contingent that had established itself in the former Russian province of Georgia, and shots were exchanged. The Germans threatened to withdraw all their support from the Ottoman regime and the incident was unsatisfactorily resolved, while Enver pressed his brigades to advance as fast as they could to Baku. To add grandeur to this final dash, he styled his force 'The Army of Islam', but it was a poor attempt to generate support. They reached Baku in time to deal with a massacre of Muslims and a counter-massacre of Christian Armenians, having met some resistance from a small British contingent under General Dunsterville. The British were evacuated. But the fact was that the Ottoman Empire had reached the end of its resources. There were widespread shortages on the home front and the fighting fronts. Malaria and diseases related to malnutrition had ravaged the Ottoman forces in Palestine. In the southern Caucasus, one Turkish cavalry officer, observing his own troops, had noted: 'their stomachs are totally empty - like the imperial treasury.' He added: 'They have no shoes [and] you can see their whole bodies through their ragged clothes. ${ }^{21}$ Ottoman divisions had been reduced to the size of battalions, regiments to companies, and companies to sections. Horses were in short supply making the movement of guns and munitions almost impossible. The end was coming.

As the Ottoman Army argued and struggled to shore up its Syrian front, and to reinforce the defences around Amman, which seemed to be the next target of the Egyptian Expeditionary Force, General Allenby struck with his full might at Megiddo in September 1918. The breakthrough was immediate and opened up a gap of seven miles, through which poured the Desert Mounted Corps. The horsemen rode deep into the Ottoman-German rear, overrunning meagre depots and capturing headquarters staff. The Arab Northern Army, which had contested Tel Afar and Ma'an, now pursued the Ottomans relentlessly. The Ottoman formations withdrew, broke up and then fled as a disorganised mass. Megiddo was a decisive victory, the culmination of careful preparation and elaborate deception. The assault was a model example of combined arms operations, each branch working in concert with the rest. The mounted troops were covering almost a thousand yards every minute, while the air force swooped and strafed the retreating Ottoman forces. Within days, the Allies were in Damascus and heading towards Aleppo.

\footnotetext{
${ }^{21}$ Serezli Ismail, Diary, January 1918, IWM, translated courtesy of Leo Gough.
} 
The collapse of the Ottomans in Palestine coincided with their defeat in northern Mesopotamia, where General Marshall subsequently took possession of Mosul, and the defeat of Bulgaria in the Balkans. The decision of Sofia to sue for peace severed the critical rail link to Germany and made the Ottoman surrender inevitable. Lloyd George had, to some extent, been vindicated in his prediction that 'knocking away the props' would compel Germany to conduct peace negotiations, but the British army could also argue that the Allied effort in France and Flanders had been critical in breaking the Germans. It was here that the German spring offensive of 1918 was eventually halted, and then driven back. By the time Allenby had broken the Ottomans at Megiddo, the Hindenburg Line had been pierced and the German army was already being pushed back towards its own borders.

If the war in Europe was coming to an end, the conflict in the Middle East was not. There were a further four years of peace-making ahead, from 1919-1923, and there were conflicts in the Caucasus, Russia, Central Asia, and Afghanistan. There was civil unrest and widespread violence in Egypt, parts of India and Persia. There was an uprising in northern Iraq in 1919 and an even more extensive revolt in 1920 which necessitated as many troops to quell as had been required in the 1917 operations. The Turks were at war again too - against France and the Greeks. There was almost a subsequent conflict with Britain at Chanak, until diplomacy solved the problem. The point is that strategic decisions continued to impact upon the peace, just as they had the war.

Lloyd George and Clemenceau had their own agendas. These were brought out in an alleged exchange between the two men at the end of the war. Lloyd George insisted that Britain 'must have Mosul' and Clemenceau, inscrutable, agreed without protest. Lloyd George pressed again, expecting resistance, and stated: 'We must have Palestine'. Once again, Clemenceau concurred. Lloyd George apparently enquired why this experienced French politician, so famous for his fiery demands for 'guerre à l'outrance', seemed to put up no fight at all. Clemenceau confessed that he had no interest in the Middle East, and that he only had to ensure that 'Syrie' was acquired to maintain the support of the Colonial lobby in Paris.

The strategies and decisions about the Middle East had been iterative, responses to events framed within national and imperial interests. There was no 'grand conspiracy' to subjugate the peoples of the region. Indeed, as the de Bunsen Committee findings made clear in 1915, Britain had tried to ensure the autonomy of the Ottoman communities and aimed to protect the independence of its own allies and partners in the Gulf and southern Arabia. It faced difficult choices, particularly when partners chose to wage war on each other, such as Ibn Saud and Emir Hussein, or the French and Feisal's Syrian supporters. For Britain, this was the key dilemma: how was it to protect its own national interests and those of its allies? The solution was to grant independence where possible to create long-standing partners responsible for their own affairs.

The strategic balance sheet ends broadly in Britain's favour. It had fulfilled its war aims, protecting the Suez Canal and the commercial link to the east. It had secured its Arab partners and retained a buffer state, Turkey, against Russia. Persia and Afghanistan, it was reasoned, could withstand Bolshevism far better as fully independent entities, but it was also true that the costs and difficulties of maintaining direct control of their foreign policies was simply counter-productive and expensive. France, Britain's closest wartime ally, was satisfied with the peace treaties, but its ambitions had been limited to Syria and it had been excluded from Mosul and Palestine. Germany, like the Bolsheviks, were contained or driven out of the region. In later generations, Britain would continue to stand alongside monarchists, secularists and devout Muslims against communist ideologues without fear of contradiction.

In contrast, the narrative that developed in Turkey was less well disposed towards the Arabs who were accused of having let down the Ottoman Empire, and, in some cases, indulged in betrayal. The Turks were so disenchanted with the old order, with the Ottoman defeat in a war of folly, and all its pretences to greater inclusiveness, that they abolished the Caliphate in 1924 in favour of an ethnically homogenous nation state. From this period, Gallipoli was remembered entirely as a Turkish military achievement and Kemal 'Ataturk' was regarded as instrumental in it. Today, sadly, even this military success is being distorted by a government that applauds those Islamist scholars who argue that it would simply not have been possible to turn back the world's greatest empire with human efforts: their answer is that it was divine intervention by Allah himself that turned the tide. 
In this brief exposition, there is much that, necessarily, has been omitted. But my work on The Great War and the Middle East has set out to be a small contribution to the historiography of that war and the region. ${ }^{22}$ It suggests that war creates its own extrinsic pressures, and the dynamics of strategic or operational interactions can shift war aims and peace plans significantly. It indicates that 'agency', by individual leaders, local groups and military forces, can play a part, as can the domestic agendas of the belligerent powers. It is clear that the war produced its own dynamic, which generated a wave of brutalities against certain minority groups. To understand that pivotal moment in the history of the Middle East, we must, I think, focus carefully on the decision-makers and the making of strategy. Perhaps recent events in Syria and Iraq, and especially the emergence of groups claiming some pan-Islamic unity, with their aspiration to create a Caliphate through war and conquest, can concentrate our minds still further. It was noticeable that Da'esh, or 'Islamic State', claimed to have destroyed the Sykes-Picot agreement in 2014 by demolishing border posts and murdering border police. Not only were Da'esh in the wrong place by over 100 kilometres, but, as scholars and diplomats know, they were 100 years too late, since the Sykes Picot agreement was never implemented and was repudiated by the British and French governments in 1918. To counter the narratives of extremists, history can be a useful weapon.

${ }^{22}$ Rob Johnson, The Great War and the Middle East (Oxford: Oxford University Press, 2016). 